\title{
RESENHA DE MACHADO DE ASSIS: A LITERARY LIFE, DE K. DAVID JACKSON
}

Review of Machado de Assis: a literary life, by K. David Jackson

\section{JACKSON, K. David. Machado de Assis: a literary life. New Haven \& London: Yale University Press, 2015.}

Luana Ferreira de Freitas

Universidade Federal do Ceará

Fortaleza, Ceará, Brasil

\section{Cynthia Beatrice Costa}

Universidade Federal de Santa Catarina

Florianópolis, Santa Catarina, Brasil

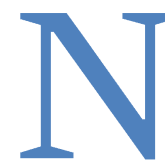

ão é raro que a crítica anglófona de Machado de Assis lamente a relativa negligência sofrida pelo escritor fora de seu país de origem. $\mathrm{O}$ volume recém-lançado Machado de Assis: A Literary Life, do brasilianista e diretor do departamento de português da Universidade de Yale, K. David Jackson, não foge a essa premissa e vai ainda mais longe, argumentando que Machado deveria ocupar, no cânone ocidental, lugar semelhante ao de Dostoievski: assim como este, teria desempenhado papel decisivo na transformação do romance realista em prosa modernista.

Embora esteja na prateleira de biografias em livrarias estadunidenses, o gênero do livro de Jackson é híbrido, revezando-se entre o ensaio biográfico e a crítica literária: com 336 páginas divididas em quinze capítulos, estes separados em cinco seções distintas, aborda fatos-chave da vida e da obra de Machado de Assis e sua herança para a literatura (Parte I); os princípios de sua escrita e a maneira como abriu espaço entre forma e sentido na narrativa (Parte II); temas característicos de sua literatura - o delírio de Brás Cubas, a filosofia de Quincas Borba e o mundo como uma ópera protagonizada pela dupla Deus e Diabo, de Dom Casmurro (Parte III); seus ilustres personagens-narradores, escritores de suas memórias - Brás Cubas, Bento Santiago e Conselheiro Aires (Parte IV); e, por fim, o papel do autor como filósofo e observador do que Jackson apelida de 
"city-universe" - sua capacidade de enxergar e expressar universalidades humanas observando a sociedade carioca da segunda metade do século XIX (Parte V).

Conhecido por seu interesse em Machado e pela literatura brasileira moderna em geral, Jackson estende e aprofunda em seu novo livro ideias já introduzidas em outras de suas publicações, como "Madness in a Tropical Manner", que debateu traduções de romances machadianos no jornal The New York Times, e, mais substancialmente, em sua Anthology of the Brazilian Short Story, da Oxford University Press, que compilou dez contos machadianos - além de outros 62 de 36 autores diferentes, como Guimarães Rosa, Clarice Lispector, Rubem Fonseca e outros mestres brasileiros do gênero.

As maiores contribuições do estudo de Jackson podem ser resumidas em duas frentes. Primeiramente, a atualizadora: ele recicla a crítica machadiana para o leitor de língua inglesa que acaba de entrar em contato com Machado de Assis, em pleno século XXI - trata-se de um apoio teórico às traduções em inglês que vêm surgindo com ânimo nos últimos anos, como as coletâneas de contos organizadas por Glenn Alan Chenney, por Rhett McNeil e por Juan LePuen, todas de 2014, e, notadamente, a nova edição de Dom Casmurro (2015) da britânica Daunt Books, que dá novo fôlego à tradução de Helen Caldwell. Depois, é inegável a sua colaboração do ponto de vista da teoria literária, ainda que Machado já tenha sido virado e revirado ao longo de décadas: para provar a sua tese de que o fundador da Academia Brasileira de Letras foi um visionário, Jackson disseca aos pormenores as estratégias literárias machadianas, tais como o diálogo com o leitor; a descontinuidade narrativa; a dissimulação; a substituição retórica; as comparações teatrais, entre outras.

Com essas incursões estilístico-filosóficas, Jackson busca atingir um de seus objetivos, que é o de listar singularidades suficientes para que se deseje um Machado mais reconhecido internacionalmente. Ao que parece, entretanto, não convence a todos. Em uma crítica ácida, a revista britânica The Spectator trata, ao mesmo tempo, do livro do professor de Yale e da nova edição de Dom Casmurro da Daunt Books - nela, nem a tradução de Caldwell, geralmente apreciada, escapa aos ataques do crítico literário Duncan Fallowell. Ele ironiza um adjetivo supostamente criado por Jackson - "Machadean", que corresponderia ao nosso largamente usado "machadiano" do português - e o 
acusa de adotar um tom elogioso que beira a histeria (bordering on hysteria). Um exagero, em sua opinião, para um escritor que não se compara a Dickens ou Gogol. Seu texto, porém, é marcado por idiossincrasias: ele define o estilo de Machado como "rococó" e denuncia uma suposta ausência de Brasil (onde estão Pantanal, Amazônia e o mar?) em seus romances, que, além de tudo, seriam, segundo ele, quase idênticos entre si.

Embora a observação de que Jackson deixa transparecer sua grande admiração por Machado tenha algum embasamento - ele o classifica, afinal, como o possível maior escritor da história da América Latina -, há um claro esforço de sua parte em apresentar argumentos palpáveis que justifiquem essa admiração. Sua convivência com o "Wizard of Cosme Velho" vem de longa data. No prefácio, ele recorda os seus quarenta anos de leitura do autor brasileiro e cita os estudiosos que mais tiveram impacto em seu percurso, como José Barreto Filho, Agripino Grieco, Raimundo Magalhães Júnior e Benedito Nunes, além de seu respeito pelas colaborações da compatriota Helen Caldwell.

Como em todo trabalho opinativo, não é de se estranhar que haja favorecimentos e omissões. Pela maneira como fez a sua seleção bibliográfica, Jackson indica a clara preferência por abordagens de cunho estético, psicológico e filosófico, e menos atenção a possíveis interpretações sociológicas da obra machadiana, não cobrindo, por exemplo, os trabalhos de John Gledson e Roberto Schwarz.

A edição da Yale University Press traz, ao final, os créditos das traduções de Machado para o inglês usadas por Jackson nos exemplos, 147 notas explicativas, um índice remissivo abrangente e referências bibliográficas acompanhadas de um comentário. Trata-se, enfim, de mais uma fonte relevante para o estudioso atual de Machado, que, como ressalta o próprio Jackson, tem à sua frente uma bibliografia "practically inexhaustible" (2015, p. 4) - praticamente inesgotável. 


\section{Referências}

ASSIS, Machado de. Dom Casmurro. Trad. Helen Caldwell. London: Daunt Books, 2015. . Midnight Mass and Other Stories (e-book). Org. e trad. Juan LePuen. Fario, 2014. . Stories. Org. e trad. Rhett McNeil. McLean/IL and London: Dalkey Archive Press, 2014.

FALLOWELL, Duncan. Machado de Assis Wasn't the Dickens of Brazil - But He is One

of the Greats. In: The Spectator. 2015. Disponível em: http://www.spectator.co.uk/books/9605362/machado-de-assis-wasnt-the-dickensof-brazil-but-he-is-one-of-the-greats. Acesso em: 12 ago. 2015.

JACKSON, K. David. Machado de Assis - A Literary Life. New Haven \& London: Yale University Press, 2015.

. Madness in a Tropical Manner. In: The New York Times On The Web. 1998.

Disponível

em:

http://www.nytimes.com/books/98/02/22/reviews/980222.22jacksot.html. Acesso em: 12 ago. 2015.

- Oxford Anthology of the Brazilian Short Story. Oxford/New York: Oxford University Press, 2006.

LUANA FERREIRA DE FREITAS é doutora em Teoria Literária, pela Universidade Federal de Santa Catarina, e atualmente é professora na Universidade Federal do Ceará, onde atua na área de literatura. É uma das fundadoras e primeira coordenadora da POET - Pós-Graduação em Estudos da Tradução (UFC) e vice-coordenadora do GT de Tradução da Anpoll, gestão 2014-2016. Organizou em conjunto com Walter Carlos Costa o I Colóquio Machado de Assis, Literatura \& Tradução, em abril de 2015, na UFC. Publicou "Sterne em Memórias póstumas de Brás Cubas e Dom Casmurro", Machado de Assis em Linha, v. 7, p. 183-197, 2014; e, em conjunto com Cynthia Beatrice Costa, "Machado contista em antologias em língua inglesa", na Cadernos de Tradução, v. 35, p. 69-85, 2015; e "Casa Velha / The Old House, de Machado de Assis", tradução de Mark Carlyon, na Cadernos de Tradução (UFSC), v. 2, p. 283292, 2014. E-mail: luanafreitas.luana@gmail.com.

CYNTHIA BEATRICE COSTA possui formação em Comunicação Social e mestrado em Crítica Literária, pela PUC-SP. Atualmente, faz doutorado no Programa de Pós-Graduação em Estudos da Tradução da Universidade Federal de Santa Catarina (UFSC), sobre traduções em inglês do romance Dom Casmurro. É também sócia-editora da Editora Poetisa, especializada em traduções literárias. Em conjunto com a Profa. Dra. Luana Ferreira de Freitas, publicou 
recentemente "Machado contista em antologias em língua inglesa", na Cadernos de Tradução, v. 35, p. 69-85, 2015, e "Casa Velha / The Old House, de Machado de Assis", tradução de Mark Carlyon, na Cadernos de Tradução (UFSC), v. 2, p. 283-292, 2014. E-mail: cynthia@editorapoetisa.com.br.

Recebido: 18.08.2015

Aprovado: 19.10.2015 